\title{
BIOLOGICAL CONTROL OF FRUIT PATHOGENS
}

\author{
P.A.G. ELMER ${ }^{1}$, S.M. HOYTE ${ }^{1}$, J.L. VANNESTE ${ }^{1}$, T. REGLINSKI ${ }^{1}$, \\ P.N. WOOD ${ }^{2}$, and F.J. PARRY ${ }^{1}$ \\ ${ }^{1}$ HortResearch, Private Bag 3123, Hamilton, New Zealand \\ ${ }^{2}$ HortResearch, Private Bag 1401, Havelock North, New Zealand \\ Corresponding author: pelmer@hortresearch.co.nz.
}

\begin{abstract}
Disease management in fruit crops worldwide is heavily dependent upon the application of synthetic fungicides for pathogen control. However, restrictions on fungicide use and widespread emergence of pathogen resistance has increased global demand for more sustainable production systems and driven research towards alternative disease control strategies. Biological control, which includes elicitors of host defence, microbial antagonists and natural products, offers an attractive alternative to synthetic pesticides. This paper reviews the commercialisation of biological control agents for botrytis in grapes (BOTRY-Zen®) and fire blight in apples and pears (Blossom Bless ${ }^{\circledR}$, PomaVita $\left.{ }^{\circledR}\right)$, and the development of a biological control agent for sclerotinia in kiwifruit. The importance of understanding disease epidemiology as a prerequisite for developing a biological control system is discussed, along with future prospects for biological control of these pathogens.

Keywords: botrytis, grapes, sclerotinia, kiwifruit, fire blight, apples, pears.
\end{abstract}

\section{INTRODUCTION}

Over the last two decades, biological control of plant pathogens has emerged as a viable disease control strategy (Harman 2000; Elad \& Stewart 2004). Numerous factors are responsible for increasing interest in biological control including the negative effects of fungicides on human health (White 1998), increased regulatory restrictions (Janisiewicz \& Korsten 2002), traceability protocols for crop protection practices (e.g. EUREPGAP), nil residue tolerance in some export markets, continued interest in organics (Chamberlain 2001), pathogen resistance to commonly used fungicides (Rosslenbroich \& Stuebler 2000) and bactericides (McManus et al. 2002), and a lack of replacement products.

Mechanisms of biological control agents (BCAs) are diverse and include the induction of plant resistance by elicitors, the interference of pathogen infection pathways with antagonistic micro-organisms and direct suppression of pathogens with antimicrobial natural compounds. These different, yet complementary, approaches for disease control have shown great promise in laboratory conditions, but many have failed to realise their potential in the field due to various unforeseen biological, technical, economic or regulatory hurdles (Fravel 1999). Despite these difficulties, new biological control products are coming onto the market place.

This paper reviews progress of biological control in three fruit-pathogen systems, describes identified gaps in our knowledge and outlines prospects for the future.

\section{BOTRYTIS IN GRAPES}

Botrytis cinerea (Pers.:Fr.), the causal agent of botrytis, grey mould or bunch rot of grapes, is responsible for significant economic damage in vineyards worldwide. Disease management has been dependent upon synthetic chemicals, with new compounds replacing old chemical groups as fungicide resistance develops (Rosslenbroich \& 
Stuebler 2000). However, resistance to relatively new compounds (e.g. cyprodinil and fenhexamid) has now occurred in the field (Leroux 2004).

Successful biological control of botrytis is dependent upon thorough knowledge of the ecology and epidemiology of B. cinerea in vineyards (Elmer \& Michailides 2004). In spring, conidia from saprophytically surviving mycelium and germinating sclerotia infect senescing floral tissues (e.g. calyptra and aborted fruitlets), tender young shoots and leaves in the grapevine (Seyb 2004). Physical and chemical host defences limit early season infections of green tissues and these enter a quiescent or latent phase in the bunch. Pathogenic development resumes at veraison as host defences naturally begin to decline (Pezet et al. 2003). Post-veraison infections can also arise from airborne conidia or from saprophytic mycelia from necrotic tissues within the bunch (Latorre et al. 2002). Late season rains can result in botrytis proliferation in the grape bunch and substantial crop loss at vintage.

Early season protection of senescent and necrotic floral tissues by fungicides, significantly reduces bunch rot at vintage (Elmer \& Michailides 2004). An isolate of the saprophytic fungus Ulocladium oudemansii (Simmons.) was identified as an effective antagonist of $B$. cinerea on necrotic grape tissues (Elmer et al. 2003). Aggressive colonisation of necrotic bunch trash tissues by $U$. oudemansii early in the season is the primary mode of action (Shorten et al. 2003).

A Technology for Business Growth (TBG) grant was established between New Zealand Winegrowers (NZWG) and HortResearch to further develop this BCA for early season control of botrytis in grapes. The first commercial formulation of U. oudemansii (BOTRY-Zen ${ }^{\circledR}$ ) was developed in 2001 and independent evaluation was carried out by HortResearch in two Hawke's Bay vineyards over three growing seasons (2002/03-2004/05). A randomised block design was used and plots consisted of five vines; the number of replicates per treatment varied from 4-6 depending on the season. There were three treatments including a non-botryticide control. The fungicide programme was based upon recommendations by major Hawke's Bay wineries; Shirlan ${ }^{\circledR}$ and Switch $\AA$ applied at $5 \%$ and $90 \%$ flowering, Euparen ${ }^{\circledR}$ DF or Teldor ${ }^{\circledR}$ at prebunch closure (PBC), Scala ${ }^{\circledR}$ at veraison and captan and/or Rovral ${ }^{\circledR}$ Flo pre-harvest. The BOTRY-Zen ${ }^{\circledR}(\mathrm{BZ})$ programme was BZ $\left(2 \times 10^{6}\right.$ conidia $\left./ \mathrm{ml}\right)$ applied at $5 \%$ and $90 \%$ flowering, pea size and $\mathrm{PBC}$, followed by the same veraison and pre-harvest botryticides used in the 'fungicide' treatment. In 2005, Teldor® was used instead of BZ at PBC. Flowering sprays were applied at 500 litres/ha and thereafter at 800 litres/ha. Botrytis control efficacy ranged from $83 \%$ to $92 \%$ and was always equivalent to that achieved with full season botryticides (Table 1).

These findings confirmed that BOTRY-Zen ${ }^{\circledR}$ programmes were as effective as botryticide programmes over a range of growing seasons and botrytis disease pressure.

Late season conidial infection of grape berries and mycelial infection between berries occurs if weather and inoculum conditions favour disease development. The saprophytic mode of action of BOTRY-Zen ${ }^{\circledR}$ suggests that it is unlikely to provide late season protection of ripening berries. Research has now focused on selecting a post-veraison BCA to complement early season BOTRY-Zen®. A natural product elicitor of host defence (Rua II) and a yeast-like fungus (HRAb) were field evaluated in the same trials described above in 2003/04 and 2004/05. When early season BOTRY-Zen $\AA$ applications were followed by post-veraison applications of Rua II or HRAb, botrytis control efficacy ranged from $53 \%-82 \%$. These findings indicate that full season biological control of $B$. cinerea in vineyards is possible and that complete replacement of synthetic botryticides is a realistic goal. 
TABLE 1: A summary of the field efficacy of the biological control product BOTRY-Zen ${ }^{\circledR}$ against botrytis bunch rot in Chardonnay grapes in comparison to standard fungicide programmes used in Hawke's Bay vineyards (2002-05).

\begin{tabular}{|c|c|c|c|c|}
\hline Year & Cultivar clone & Treatment & $\begin{array}{c}\text { Crop loss } \\
(\%)^{1}\end{array}$ & $\begin{array}{c}\text { Efficacy } \\
(\%)^{2}\end{array}$ \\
\hline \multirow[t]{5}{*}{$2002 / 03$} & Chardonnay UDC $6^{3}$ & Untreated $^{4}$ & 11.1 & \\
\hline & & Fungicide & 0.4 & 96 \\
\hline & & BOTRY-Zen® & 1.0 & 91 \\
\hline & & U.oudemansii HRU3 ${ }^{5}$ & 0.9 & 92 \\
\hline & & $\operatorname{LSD}(\mathrm{P}<0.05)$ & 2.5 & \\
\hline \multirow[t]{4}{*}{ 2003/04 } & Chardonnay UDC $15^{6}$ & Untreated & 17.7 & \\
\hline & & Fungicide & 3.5 & 78 \\
\hline & & BOTRY-Zen ${ }^{\circledR}$ & 2.7 & 83 \\
\hline & & $\operatorname{LSD}(\mathrm{P}<0.05)$ & 5.0 & \\
\hline \multirow[t]{4}{*}{$2004 / 05$} & Chardonnay UDC $15^{6}$ & Untreated & 51.8 & \\
\hline & & Fungicide & 5.8 & 89 \\
\hline & & BOTRY-Zen ${ }^{\circledR}$ & 9.8 & 81 \\
\hline & & LSD $(\mathrm{P}<0.05)$ & 9.5 & \\
\hline
\end{tabular}

${ }^{1}$ Crop loss is the product of $B$. cinerea incidence and severity assessed visually at vintage and is an estimate of the total crop infected by botrytis, expressed as a percentage.

${ }^{2} \%$ Efficacy $=[($ untreated minus treated $) /$ untreated $] \mathrm{x} 100$.

${ }^{3}$ Located at the HortResearch Lawn Rd Research Centre, Hastings, Hawke's Bay.

${ }^{4}$ Received regular applications of sulphur fungicides for powdery mildew control.

${ }^{5}$ Unformulated BCA isolate was prepared at HortResearch, Ruakura Research Centre and used as a comparative check in the early stages of commercialisation.

${ }^{6}$ Located in a commercial grower's vineyard, Havelock North, Hawke's Bay.

\section{FIRE BLIGHT IN APPLES AND PEARS}

Fire blight is a bacterial disease of apples and pears caused by Erwinia amylovora (Burr.) that prevents export of these fruit to fire blight-free countries and can destroy an established orchard within one season (Vanneste 2000). Chemical control of fire blight is mostly limited to the use of heavy metals or antibiotics; both types of compounds have disadvantages (Psallidas \& Tsiantos 2000). Copper derivatives are phytotoxic and have been found to accumulate in the soil leading to toxicity problems. Furthermore, copper-resistant strains of plant pathogenic bacteria have been isolated in New Zealand (Vanneste \& Voyle 2003). Similarly, the repeated use of streptomycin can lead to selection of strains of E. amylovora resistant to this antibiotic (Vanneste \& Voyle 2002). Control of bacterial pathogens using selected non-pathogenic bacteria has shown some promise for a number of diseases, in particular fire blight (Johnson \& Stockwell 2000). A strain of Pantoea agglomerans (formerly Erwinia herbicola) isolated from blossoms collected in a pear orchard in New Zealand was found to consistently reduce fire blight incidence on immature pear fruit in the laboratory. This strain, called P10c, when applied prior to inoculation with E. amylovora reduced incidence of fire blight on apple and pear flowers (Vanneste et al. 2002).

Fire blight starts in spring when apple and pear flowers are infected with cells of $E$. amylovora transferred to the blossoms from cankers where it over-winters. Before infecting a flower, E. amylovora colonises the stigmatic surfaces of the flower. Therefore, the ability to establish on and colonise apple and pear flowers, thus depriving E. amylovora of its ecological niche, is an important characteristic for a BCA of fire blight. The strain P10c of P. agglomerans was selected from other potential BCAs for its ability to rapidly colonise apple and pear flowers. After artificial inoculation of apple flowers in the laboratory, $\mathrm{P} 10 \mathrm{c}$ reached populations of $10^{6}$ to $10^{7} \mathrm{cfu} / \mathrm{flower}$ within 
$48 \mathrm{~h}$ (Vanneste et al. 2002). This is the maximum number of bacteria that can grow on the stigmatic surface of an apple flower due to the amount of nutrients available and/or due to the limiting space available for growth (Wilson \& Lindow 1993).

The ability of P10c to protect against fire blight was initially assessed on cores of immature pear fruits in the laboratory (Vanneste et al. 1996). In all cases, immature pear fruits treated with P10c were significantly less affected by fire blight than non-treated fruits. The ability of this strain of $P$. agglomerans to reduce incidence of fire blight on flowers was then demonstrated using pear branches in the laboratory. Branches of pear $\mathrm{cv}$. Conference were brought from the orchard and flowers that opened in the laboratory were treated with either water or P10c and inoculated two days later with E. amylovora strain 1540 at $3 \times 10^{6} \mathrm{cfu} / \mathrm{ml}$. The presence of exudate on flowers, signalling fire blight infection, was assessed every day. Significantly fewer flowers treated with P10c showed symptoms than those treated with water (Vanneste et al. 2002).

In an experiment carried out on potted pear trees in the glasshouse, where, $24 \mathrm{~h}$ after application of P10c or streptomycin $(100 \mathrm{ppm})$, flowers were inoculated with E. amylovora, the level of control obtained with P10c was similar to that obtained with streptomycin (Table 2) (Vanneste et al. 2002). Similar experiments were conducted in three different apple orchards located in the Waikato, New Zealand. Bacterial suspension of P10c (1-2 x 10 $\left.10^{8} \mathrm{cfu} / \mathrm{ml}\right)$, streptomycin $(100 \mathrm{ppm})$ or water was sprayed to run-off on newly open blossom clusters. The next day the same blossom clusters were sprayed with an aqueous suspension of E. amylovora ranging from $5 \times 10^{5}$ to $1 \times 10^{7} \mathrm{cfu} / \mathrm{ml}$, depending on the experiment. The number of healthy and diseased clusters was recorded several weeks after inoculation. In all these experiments the level of control obtained with P10c was similar to that obtained with streptomycin (Table 3) (Vanneste et al. 2002). Similar results have been obtained in pear orchards in New Zealand, and in experiments carried out overseas (J.L. Vanneste, unpubl. data).

TABLE 2: Percentage of pear flowers on potted pear trees in the glasshouse showing fire blight infection and percentage of disease control (infection relative to water-treated flowers) after treatment with P10c or streptomycin and inoculation with $E$. amylovora.

\begin{tabular}{lcc}
\hline Treatments $^{1}$ & Percent infection $^{2}$ & Percent disease control \\
\hline Water & 77 & - \\
Streptomycin & 47 & 39 \\
P10c & 49 & 36 \\
\hline
\end{tabular}

${ }^{1}$ Source of data (Vanneste et al. 2002).

${ }^{2} \operatorname{LSD}(\mathrm{P}<0.05)=18.6$.

TABLE 3: Percentage of apple clusters with fire blight infection after treatment with P10c, streptomycin or water and inoculation with $E$. amylovora. Experiments were conducted in orchards in the Waikato, New Zealand. Data from Vanneste et al. (2002).

\begin{tabular}{lrrrc}
\hline & \multicolumn{4}{c}{ Experiments } \\
\cline { 2 - 5 } Treatments & I & II & III & IV \\
\hline Water & 53.0 & 46.0 & 28.7 & 74.9 \\
Streptomycin & 5.2 & 4.0 & 16.0 & 43.9 \\
P10c & 9.1 & 6.0 & 15.3 & 51.5 \\
\hline
\end{tabular}

$\mathrm{P} 10 \mathrm{c}$ has been demonstrated to be one of the most effective strains of bacteria for control of fire blight. It is formulated as a commercial product called Blossom Bless ${ }^{\circledR}$ now on sale in New Zealand and it is also produced and distributed in Italy under the name PomaVita ${ }^{\circledR}$. These wettable powder formulations can be sprayed directly onto 
flowers or delivered to flowers using honeybees (Vanneste et al. 1999). In both cases, under optimum conditions, $100 \%$ of the flowers randomly sampled in treated commercial orchards were colonised by P10c.

\section{SCLEROTINIA IN KIWIFRUIT}

Sclerotinia sclerotiorum (Lib.) de Bary has a very wide host range and is responsible for blossom rot, soft fruit rot and pre-harvest cosmetic defects in kiwifruit (Actinidia deliciosa (A. Chev.). Crop loss typically ranges from $0-4 \%$ but can exceed $15 \%$ in high risk blocks (Hoyte 2000). Disease control is largely based upon a maximum of two applications of iprodione (Rovral Flo $\left.{ }^{\circledR}\right)$, applied during flowering and up to within 100 days of harvest. Market demands for nil fungicide residue fruit have stimulated interest in biological control as an alternative to iprodione.

Epidemiological studies (1995-2000) demonstrated that there are two important stages in disease development. Firstly, petals become infected by ascospores during flowering and petal-fall and secondly, floral tissues infected by sclerotinia that remain adhered to fruit act as an important inoculum source for the development of cosmetic scarring and fruit rot (Hoyte 2000). Protection of petals from S. sclerotiorum infection during flowering and petal fall was therefore considered to be an ideal target for a BCA (Elmer et al. 2001). A biological control programme was initiated in 1997; potential BCAs were recovered from kiwifruit microflora and screened using petal infection bioassays, anti-microbial bioassays and growth and sporulation characteristics. Isolates of Epicoccum nigrum Link. (syn. E. purpurascens) showed significant suppressive activity against infection of gamma sterilised kiwifruit petals by sclerotinia ascospores. Epicoccum nigrum also suppressed fruit scarring in a field assay when applied to kiwifruit petals that had been pre-inoculated for $48 \mathrm{~h}$ with $S$. sclerotiorum ascospores (Elmer et al. 2002).

A field spray trial was established in 1999/00 as described in Elmer et al (2001). Treatments were applied twice during flowering to five replicate vines per treatment using a randomised block design. This study confirmed that $E$. nigrum applied to kiwifruit flowers significantly $(\mathrm{P}<0.05)$ reduced sclerotinia disease on petals and fruit (Table 4). Disease control at harvest was equivalent to iprodione using double applications of high rates $\left(2 \times 10^{6}\right.$ conidia/ml $)$ of E. nigrum.

Several subsequent field trials (confidential data) have continued to demonstrate that a selected isolate of E. nigrum has good efficacy against sclerotinia at commercial application rates, and a new registered BCA product is expected to be on the market in the coming seasons. Efficacy of fungicide used to control sclerotinia has been shown to decline significantly when the timing of application is delayed by seven or 14 days after $100 \%$ flowering (Hoyte 2003). Therefore, to achieve high levels of sclerotinia disease control using BCAs, it is likely that the timing and number of applications needs to be studied further to ensure consistent and cost-effective disease control is achieved.

TABLE 4: Incidence of sclerotinia disease (\% petal infection and \% reject fruit) in a Hayward kiwifruit field trial, following two applications of the BCA and iprodione during flowering in 1999/00.

\begin{tabular}{lcc}
\hline Treatment & Petal infection & Reject fruit at harvest \\
\hline Nil & 67 & 5.3 \\
E. nigrum $\left(2 \times 10^{4} \text { conidia } / \mathrm{ml}\right)^{1}$ & 55 & 2.6 \\
E. nigrum $\left(2 \times 10^{5}\right.$ conidia $\left./ \mathrm{ml}\right)$ & 43 & 2.4 \\
E. nigrum $\left(2 \times 10^{6}\right.$ conidia $\left./ \mathrm{ml}\right)$ & 25 & 1.5 \\
iprodione $(37.5 \mathrm{~g}$ ai $/ 100 \mathrm{litres})$ & 6 & 1.3 \\
Max SE & 5.5 & 0.8
\end{tabular}

${ }^{1}$ Non-formulated BCA applied twice during flowering with $0.01 \%$ Tween80 using a knapsack sprayer. Data are adapted from Elmer et al. (2001). 
This research has highlighted that effective suppression of sclerotinia disease of flowers and fruit in kiwifruit is achievable using a saprophytic fungal BCA, and clearly demonstrates that E. nigrum has commercial potential (Hoyte 2002b). The challenge for future research is to maximise efficacy using commercially acceptable rates of E. nigrum. Ultimately, the best disease control will be achieved by combining BCAs with complementary modes of action and integrating these with other cultural control strategies, such as removal of male vine prunings and mulching a long sward at the onset of flowering (Hoyte 2002a).

\section{SUMMARY AND FUTURE PROSPECTS}

This mini review reports on the importance of understanding pathogen epidemiology to identify the targets for biological intervention. Research programmes at HortResearch have resulted in the development of three different BCAs, namely BOTRY-Zen ${ }^{\circledR}$, P. agglomerans $\mathrm{P} 10 \mathrm{c}$ (formulated as Blossom Bless ${ }^{\circledR}$ or PomaVita ${ }^{\circledR}$ ) and E. nigrum. Experience has shown that reliable and repeatable disease control was achieved, but commercial success will depend upon good, consistent field efficacy. Variable performance of BCAs in the field has been attributed to inappropriate timing, poor coverage of the target tissues and poor BCA viability (Stewart 2001). The present findings indicate a need for greater emphasis on BCA application technologies and grower education to ensure the best outcome for BCA technologies.

The current research goal is to integrate compatible biological control products that occupy different environmental niches and/or have different modes of action to improve the consistency and efficacy of disease control. For example, biosuppression of botrytis on strawberries was more effective and more consistent when Pichia guilermondii and Bacillus mycoides were applied together than when applied separately (Guetsky et al. 2002). Suppression of postharvest fruit decay was enhanced when BCAs were applied in combination with chemicals (Qin \& Tian 2005). Antagonistic fungi (U. oudemansii and $E$. nigrum) when used in combination with chemical inducers significantly enhanced biological control of botrytis in grapes (Reglinski et al. 2005). Similarly, fire blight control was enhanced when BCAs were combined with elicitor active growth regulators (F. Spinelli, unpubl. data).

There is increasing demand by major fruit and wine industries for alternative strategies because of restrictions on pesticide use and demand for residue-free product for export. Whilst this will enhance the uptake of biological control strategies, there remain significant knowledge gaps that need to be addressed in order to optimise BCA performance. Therefore, further research on application technologies in parallel with fundamental research on pathogen epidemiology, disease prediction models and cultural practices are required.

\section{ACKNOWLEGEMENTS}

We thank the New Zealand Foundation for Research, Science and Technology, Technology New Zealand, The New Zealand Winegrowers (NZWG), BOTRY-Zen Ltd and HortResearch (internal funding for P10c) for funding assistance. Valuable technical assistance has been provided by Deirdre Cornish, Brent Fisher, Ron Marsden, Joseph Taylor, Darienne Voyle and Janet Yu. Thanks also to the growers in the Bay of Plenty, Hawke's Bay and Waikato regions for their generous provision of fruit, orchard blocks and vineyards, support and encouragement throughout these research programmes.

\section{REFERENCES}

Chamberlain J 2001. Going Organic. North and South December: 36-46.

Elad Y, Stewart A 2004. Microbial control of Botrytis spp. In: Elad Y, Williamson B, Tudzynski P, Delan N ed. Botrytis: Biology, Pathology and Control. Kluwer Academic, Dordrecht, The Netherlands. Pp. 223-241. 
Elmer PAG, Hoyte SM, Marsden RM, Parry F, Reglinski T 2001. Epicoccum nigrum: A biological control agent for the control of Sclerotinia sclerotiorum in New Zealand kiwifruit (Actinidia deliciosa). The $\mathrm{XI}^{\text {th }}$ International Sclerotinia Workshop. Pp. 41-42.

Elmer PAG, Hoyte SM, Marsden RM, Parry F, Reglinski T 2002. Epicoccum nigrum: a biological control agent for the control of Sclerotinia sclerotiorum in New Zealand Kiwifruit. The $5^{\text {th }}$ International Symposium on Kiwifruit. p. 60.

Elmer PAG, Michailides TM 2004. Epidemiology of Botrytis cinerea in orchard and vine crops. In: Elad Y, Williamson B, Tudzynski P, Delan N ed. Botrytis: Biology, Pathology and Control. Kluwer Academic, Dordrecht, The Netherlands. Pp. 243272.

Elmer PAG, Reglinski T, Wood PN, Hill RA, Marsden SM, Parry F, Taylor JT 2003. Suppression of Botrytis in grapes using a combination of elicitors and fungal antagonists. $8^{\text {th }}$ International Congress of Plant Pathology. p. 43.

Fravel D 1999. Hurdles and bottlenecks on the road to biocontrol of plant pathogens. Australasian Plant Pathology 28(1): 53-56.

Guetsky R, Shtienberg D, Elad Y, Fischer E, Dinoor A 2002. Improving biological control by combining biocontrol agents each with several mechanisms of disease suppression. Phytopathology 92(9): 976-985.

Harman GE 2000. Myths and dogmas of biocontrol. Changes in perceptions derived from research on Trichoderma harzianum T-22. Plant Disease 84: 377-393.

Hoyte SM 2000. Epidemiology and management of Sclerotinia sclerotiorum in kiwifruit. $\mathrm{PhD}$ thesis, Massey University, Palmerston North, New Zealand. $225 \mathrm{p}$.

Hoyte SM 2002a. Cultural control of Sclerotinia - does it work? New Zealand Kiwifruit Journal 152: 38-41.

Hoyte SM 2002b. Sclerotinia: local research and international perspectives. The Orchardist 75(1): 35-37.

Hoyte SM 2003. Sclerotinia disease control - it's all in the timing. New Zealand Kiwifruit Journal 160: 9-13.

Janisiewicz WJ, Korsten L 2002. Biological control of postharvest diseases of fruits. Annual Review of Phytopathology 40: 411-441.

Johnson KB, Stockwell VO 2000. Biological control of fire blight. In: Vanneste JL ed. Fire blight the disease and its causative agent Erwinia amylovora. CABI Publishing, Wallingford, UK. Pp. 319-337.

Latorre BA, Rioja ME, Lillo C 2002. Effect of temperature on flower and berry infections caused by Botrytis cinerea on table grapes. Ciencia e Investigacion Agraria 29(3): 145-151.

Leroux P 2004. Chemical control of Botrytis and its resistance to chemical fungicides. In: Elad Y, Williamson B, Tudzynski P, Delen N ed. Botrytis: Biology, Pathology and Control. Kluwer Academic, Dordrecht, The Netherlands. Pp. 195-222.

McManus PS, Stockwell VO, Sundin GW, Jones AL 2002. Antibiotic use in plant agriculture. Annual Review of Phytopathology 40: 1143-1165.

Pezet R, Viret O, Perret C, Tabacchi R 2003. Latency of Botrytis cinerea Prs.: Fr. and biochemical studies during growth and ripening of two grape berry cultivars, respectively susceptible and resistant to grey mould. Journal of Phytopathology 151(4): 208-214.

Psallidas PG, Tsiantos J 2000. Chemical control of fire blight. In: Vanneste JL ed. Fire blight the disease and its causative agent Erwinia amylovora. CABI Publishing, Wallingford, UK. Pp. 199-234.

Qin GZ, Tian SP 2005. Enhancement of biocontrol activity of Cryptococcus laurentii by silicon and the possible mechanisms involved. Phytopathology 95(1): 69-75. 
Reglinski T, Elmer PAG, Taylor JT, Parry FJ, Marsden R, Wood PN 2005. Suppression of Botrytis bunch rot in Chardonnay grapevines by induction of host resistance and fungal antagonism. Australasian Plant Pathology 34: In Press.

Rosslenbroich HJ, Stuebler D 2000. Botrytis cinerea - history of chemical control and novel fungicides for its management. Crop Protection 19: 557-561.

Seyb AM 2004. Botrytis cinerea inoculum sources in the vineyard system. $\mathrm{PhD}$ thesis, Lincoln University, Christchurch, New Zealand. 227 p.

Shorten PR, Elmer PAG, Soboleva TK 2003. Adynamic model to describe the interactions between Botrytis cinerea and the biological control agent, Ulocladium oudemansii. $8^{\text {th }}$ International Plant Pathology Congress. p. 23.

Stewart A 2001. Commercial biocontrol - reality or fantasy. Australasian Plant Pathology 30: 127-131.

Vanneste JL 2000. What is fire blight? Who is Erwinia amylovora? How to control it? In: Vanneste JLed. Fire blight: the disease and its causative agent, Erwinia amylovora. CABI Publishing, Wallingford, UK. p. 370.

Vanneste JL, Cornish DA, Voyle MD, Haine HM, Goodwin RM 1999. Honey bees to distribute beneficial bacteria to apple and Asian pear flowers. Acta Horticulturae 489: 615-618.

Vanneste JL, Cornish DA, Yu J, Voyle MD 2002. P10c: a new biological control agent for control of fire blight which can be sprayed or distributed using honey bees. Acta Horticulturae 590: 231-236.

Vanneste JL, Voyle MD 2002. Characterisation of transposon, genes, and mutations which confer streptomycin resistance in bacterial strains isolated from New Zealand orchards. Acta Horticulturae 590: 493-495.

Vanneste JL, Voyle MD 2003. Genetic basis of copper resistance in New Zealand strains of Pseudomonas syringae. New Zealand Plant Protection 56: 109-112.

Vanneste JL, Yu J, Harper GE, Perry JH 1996. Plugs of immature pear fruit to assess the virulence of Erwinia amylovora and to study in the laboratory the interaction between biological control agents and the fire blight pathogen. Acta Horticulturae 411: 303-308.

White A 1998. Children, Pesticides and Cancer. The Ecologist 28(2): 100-105.

Wilson M, Lindow SE 1993. Interactions between the biological control agent Pseudomonas fluorescens strain A506 and Erwinia amylovora in pear blossoms. Phytopathology 83: 117-123. 